\title{
Biochemical Effects Of Ribavirin (Antiviral) And Ddb (Hepato Protective) Drugs In Albino Rats
}

\author{
Soliman S. Ibrahim, Amr Shalaby and Mahmoud Rabeh \\ Zoology Department, Faculty of Science, Zagazig University
}

\begin{abstract}
The present investigation has been designed to through spot light on the efficiency of these two drugs in treatment of hepatitis patients.

Cortisol, antigliadin (1gG), total protein (TP) albumin (ALB), Iron (Fe), alanine aminotransferase (ALT), aspartic aminotransferase (AST) and alkaline phosphatase (ALP) were determined in serum of normal mature male and female albino rats that injected intraperitoneally day after day with $1 \mathrm{mg} / \mathrm{kg}$ body weight of each drug separately for 3 months. The cortisol level and ALP showed significant increase in each of ribavirin or DDB treated animals, while the $\operatorname{IgG}$ concentration in ribavirin treated animals increased significantly, but it is did not vary greatly from that of the control in DDB treated animals.

On the other hand both ribavirin and DDB treated male and female rats showed significant decrease in the ALT in serum while serum AST elicited non significant decrease in each of ribavirin and DDB treated male and female. With respect to serum TP and ALB levels the result showed significant decrease in ribavirin and non significant decrease in DDB treated male and female rats. Furthermore, the serum Fe level in ribavirin treated male and female rats increased significantly but it is did not vary greatly from that of the control in DDB treated animal.
\end{abstract}

\section{Introduction}

Ribavirin is a nucleoside analog that has demonstrated efficacy in treating viral disease as monotherapy [(respiratory syncytial virus, lassa fever virus and foot and mouth disease virus infection) Hall et al., 1983 ; Wyde 1998; Robert et al., 2000 and Saad and Fawzy 2004)] and is used in combination with interferon $-\alpha$ to treated hepatitis C virus infection (McHutchinson et al., 1998 ; Davis et al., 1998 ; Reichard et al., 1998; Shane crotty et al. 2000 and Johnson et al., 2002).

Since the discovery of the broad spectrum antiviral activity of ribavirin in 1972 (Sidwell et al., 1972), it has been suggested that the active from of ribavirin is the monophosphae, (RMP) (Streeter 1973). RMP inhibits inosine monophosphae dehydrogenase (IMPDH), causing a decrease in the intracellular concentration of guanosin triphosphate (GTP) (Smith and Kirkpatrict 1980 and Streeter 1973). This decrease potentially diminishes viral protein synthesis and limits replication of viral genomes. However, inhibition of IMPDH may not be sufficient for antiviral activity (Smith et al., 1984).

Tam et al., 1999 stated that ribavirin has multiple biologic properties that are favorable for treating viral diseases, it can directly inhibit the replication of many DNA and RNA viruses, it can also act as an immunomodulator and thus promote $\mathrm{T}$ - cell - mediated immunity against viral infection (Hultgren et al., 1998, Martin et al., 1998, Ning et al., 1998 and Tam et al., 1999).

The central focus of this effect of ribavirin is the augmentation of antiviral type 1 cytokine expression, gamma interferone and tumor necrosis factor alpha and concomitant supression of type 2 cytokine level by activated $\mathrm{T}$ cells in both human and murine system (Robert, et al., 2000) they also stated that ribavirin, alone or in combination with interferon - $\alpha$, can lower serum alanine aminotransferase (ALT) level during he course of treatment of hepatitis $\mathrm{C}$ virus infection. Elevated serum ALT levels are a marker for liver damage and progressive hepatitis, and hence the 
ribarvirin- mediated lowering of ALT level is a distinct liver- specific effect of this nucleoside analog (Dusheiko et al., 1996).

Robert et al., 2000 established that, the therapeutic use of ribavirin is restricted by is toxicological profile. Prolonged administration of ribavirin is frequently associated with anemia, whose severity correlates with dose level and which is reversible upon dose reduction or cessation of treatment. Also, Johnson et al., (2002) and Patrick et al., (2002) said that hemolyic anemia is a known side effect of ribavirin therapy. The mechanism is not firmly established. However, it is known that ribavirin is converted to its phosphorylated metabolites in all cell types but the conversion back to ribavirin through dephosphorylation occurs mainly in nucleated cells. Ohno Y. et al., 1998 concluded, plasma cortisol level increased after ribavirin and interferon- $\beta$ injection, in parallel with plasma adrenocorticotropin $(\mathrm{ACTH})$ and serum growth hormone $(\mathrm{GH})$ elevation. The main adverse effect of ribavarin had been discussed by Good man and Gilman (1996), they established that, the most important and expected adverse event associated with ribavirin was haemolysis but the anemia is mild and is accompaind by reticulocytosis and hyperbilirubinemia due to extravascular hemolysis. During chronic oral therapy, gastrointestinal and central nervous system adverse effects have been noted. A dry in mouth, increased thirst, anorexia, nausea and flatulence have been reported, in addition to fatigue unrelated to anemia. Central nervous system includes headache, insomnia, and irritability.

In addition to ribavirin as antivial drug DDB (dimethyl diphenyl bicarboxylate) a synthetic mimic of the natural product of schizandrin $\mathrm{C}$, is used in china as a hepatoprotective agent to improve the liver functions of patients with hepatitis or under cancer chemotherapy (Alo Nag et al., 2001, Lu H and Li Y 2002, Chiu et al., 2003, Nakamura et al., 2003, Dutta Bergman 2003 and Chang et al., 2004).

Huber et al., 2004 showed that, in vitro experiments with hepatocytes resulted in a significant decrease of hepatocellular
ALT level in the DDB treated cells, suggesting, that DDB affects the synthesis and/or degradation of ALT in liver cells, and the normalization of ALT during DDB treat-ment does not indicate therapeutic efficacy. Also DDB was shown to protect against liver injury induced by chemical toxins such as carbon tetrachloride, thioacetamide and tetrahydroacridin (THA). Liy and Liy (2001) establish that, the alteration of mice body temperature, and the elevation of serum ALT, and mitochondria potential induced by THA were significantly inhibited by DDB treatment. On the other hand, the inhibiting effect of THA on mice hippopcampus and cortex acetylcholinesterase in vitro and in vivo were not influenced by DDB treatment. In addition, DDB significantly increased the liver detoxicating ability and antagonized the mutagenicity of chemical carcinogens such as aflatoxin B (AFB). DDB (300 mg/ $\mathrm{kg})$ pretreatment provided significant protection against AFB hepatotoxicity as evidenced by the decrease of AFB- elevated serum marker enzymes in rats. The results indicate that DDB protected rats against AFB hepatotoxicity by increasing the detoxifying metabolism of AFB in the liver ( $L u$ H.,Li.Y. 2002).

Mammalian hepatitis B viruses encode an essential regulatory protein, termed $\mathrm{X}$, which may also be implicated in liver cancer development associated with chronic infection (Francoise et al., 2002). Schek et al., (1991) reported that the feature of $\mathrm{x}$ protein is its rapied turnover. Francoise et al., (2002) establish a direct functional connection of $\mathrm{X}$ with the DDB heterodimer; (DDB1 and DDB2 which is a fraction of DDB after mutation). DDB1 markedly increase $\mathrm{X}$ stability which appears to directly protect $X$ from the degradation process, whereas DDB2 acts on $\mathrm{X}$ stability in an indirect way involving the formation of the DDB heterodimer. There is a physical interaction occurring within the tripartite X-DDB complex mediate these effects through the modulation of proteasome - dependent degrading of $\mathrm{X}$. They concluded from these observation that in the presence of an excess amount of DDB1 subunit, the proteasome pathway can 
no longer operate on $\mathrm{X}$ protein, whereas further addition of the DDB2 subunit restores $\mathrm{X}$ targeting to proteasome mediated degradation.

Wittschieben and Wood (2003) said that a group of recent publications contribute new insights concerning the role of the DNA damage - binding protein complex (DDB) in DNA repair, they concluded, it appear that DDB assists in nucleotide excision repair in chromatin. Also DDB has implicated in global genomic repair as well as in transcription of cell cycle genes. (Hwang et al., 1996, Hwang et al., 1999, Tang et al., 2000 and Alo Nag 2001).

Finally administration of $180 \mathrm{mg}$ of ribavirin $\mathrm{kg} / \mathrm{day}$ in mice was associated with lower food consumption, lower body weight and decrease in erythrocyte count, hemoglobin, hematocrit, leukocyte count and increased extramedullary hematopoiesis in the spleen (Robert et al., 2000).

\section{Materials And Methods}

Ribavirin (L - B - D ribofuranosyl $1 \mathrm{H}-1,2,4$ - Triazole - 3 carboxamide) is a synthetic nucleoside with antiviral activity, manufactured by OCTOBER PHARMA S.A.E. 6- October City Egypt.

DDB (dimethyl- 4, 4' - dimethyloxy $5,6,5$, 6' dimethylenedioxy biphenyl - 2 , 2 - dicarboxylate) is a synthetic analogue of schizandrin $\mathrm{C}$ which is isolated from fructus schizandrae Chinese a traditional Chinese medicinal plant (Chang et al., 2004). It is manufactured by Beijing Union Pharmaceutical Factory Beijing P.R. China. 36 sprague - Dawley rats (18 males and 18 females) weighing 150- 170 grams from Veterinary Medicine Farm, Zagazig University were used in the present study.

Animal were allowed to acclimate to laboratory conditions for 2 weeks before experimental manipulation, and fed ad libitum. They were divided into 6 groups $(6$ males in each of $1^{\text {st }}, 3^{\text {rd }}$ and $5^{\text {th }}$ groups and 6 females in each of $2^{\text {nd }}, 4^{\text {th }}$ and $6^{\text {th }}$ groups).

Animals of the $1^{\text {st }}$ and $2^{\text {nd }}$ groups were used as controls and were injected intraperitoneally with $1 \mathrm{ml} / \mathrm{kg}$ body weight of normal saline. Animals of the $3^{\text {rd }}$ and $4^{\text {th }}$ groups were injected intraperitoneally with $1 \mathrm{mg} / \mathrm{kg}$ body weight of ribavirin. Rats of the $5^{\text {th }}$ and $6^{\text {th }}$ groups were injected intraperitioneally with $1 \mathrm{mg} / \mathrm{kg}$ body weight of DDB.

Treatments of all groups were carried out every other day for 3 months.

Individual blood samples were collected after decapitation and kept at room temperature for 2 hours, then centrifuged for 5 minutes at $5000 \mathrm{rpm}$. Collected sera were aliquoted and stored at $-20{ }^{\circ} \mathrm{C}$ until use.

The Active Cortisol RIA Dsl - 2100 kit provides materials from Diagnostic System Laboratories, Inc. Corporate Headquarters, 445 Medical Center, USA. It was determined according to (Schlaghecke et al., 1992).

Immunometric Enzyme Immunoassay for the quantitative determination of AntiGliding Antibodies of IgG class (ELISA) (Ralph 1988).

Kits from Biomerieux Lab Reagent and Products (France) were used for the determination of alanine aminotransferase (ALT), aspartate aminotransferase (AST) according to (Reitman and Frankel, 1957), alkaline phosphatase (ALP) according to (Roy, 1970), albumin (ALB) according to (Doumas et al., 1971) and serum total protein (Tp) according to (Lowry et al., 1951).

Serum iron was determined by Atomic Absorption Spectrophotometry (FMD3, Germany). Serum samples were deproteinized and diluted with deionized water. A standard iron solution was prepared to give $1 \mu \mathrm{g} / \mathrm{dl}$ and serially diluted to cover the range for iron standard curve (Dean et al., 1997).

Data were analyzed by student's t test for each statical comparison according to (Selvin, 1996).

\section{Results}

\section{* Cortisol level:}

Table (1) and fig. (1) revealed that ribavirin and DDB were able to increase the level of cortisol significantly $(\mathrm{P}<0.001)$ in male rats by $36.5 \%$ and $25.0 \%$ and in 
females by $17.5 \%$ and $10.3 \%$ above the control respectively.

* Anti - gliadin (1gG) level:

Table (2) and fig (2) show a significant increase $(\mathrm{P}<0.001)$ of $\mathrm{IgG}$ concentration by $12.5 \%$ and $23.67 \%$ above the control in ribavirin treated male and female rats respectively, whereas, no significant change was observed in this parameter in DDB treated male and female rats.

\section{* Alkaline phophatase (ALP) level:}

Table and fig. (3) represent the effect of riavirin and DDB on serum ALP in male and female rats, it shows that ribavirin and DDB administration is accompanied by significant increase $(\mathrm{P}<$ 0.001 ) in ALP by $24.7 \%$ and $27.1 \%$ in ribavirin and by $17.8 \%$ and $21.2 \%$ above the control in DDB treated male and female rats respectively.

\section{* Alanine aminotransferase (ALT):}

As shown in table (4) and Fig. (4) Ribavirin and DDB treatment caused significant decrease $(\mathrm{P}<0.001)$ in serum ALT by $52.62 \%$ and $34.58 \%$ in ribavirin and by $37.38 \%$ and $21.62 \%$ in DDB treated male and female rats respectively.
* Aspartate aminotransferase (AST):

Table (5) and fig. (5) demonstrate no significant change of serum AST following treatment of male and female rats with either ribavirin or DDB.

\section{* Total protein (Tp):}

Total protein level in serum of male and female rats showed a significant decrease $(\mathrm{P}<0.001)$ by $16.02 \%$ and $22.07 \%$ below the controls respectively, whereas no significance change in its level was recorded in DDB treated male and female rats respectively (Table 6 and Fig. 6).

\section{* Albumin (ALB):}

Table (7) and Fig. (7) illustrate that the level of serum ALB in ribavirin treated male and female rats decreased significantly $(\mathrm{P}<0.001)$ by $29.05 \%$ and $19.58 \%$ below the controls respectively, whereas, its level in serum of DDB treated male and female rats showed no significant change.

* Iron (Fe):

Data presented in Table (8) and Fig. (8) show that serum Fe was increased significantly $(\mathrm{P}<0.001)$ in ribavirin reated male and female rats by $29.40 \%$ and $33.41 \%$ above the controls respectively, but it was not affected significantly in DDB treated male and female rats.

\begin{tabular}{|l|l|l|l|}
\hline & Control & Ribavirin & DDB \\
\hline Male (mean \pm S.E. $)$ & $0.52 \pm$ & $0.71 \pm 0.65 \quad \pm$ \\
& 0.02 & $0.03 *$ & $0.03 *$ \\
\hline$\%$ of change & & $+36.5 \%$ & $+25.0 \%$ \\
\hline Female (mean \pm S.E. $)$ & $0.58 \pm$ & $0.68 \pm$ & $0.64 \pm$ \\
& 0.05 & $0.04 *$ & $0.04 *$ \\
\hline$\%$ of change & & $+17.14 \%+10.3 \%$ \\
\hline (P < 0.001) & & & \\
\hline
\end{tabular}

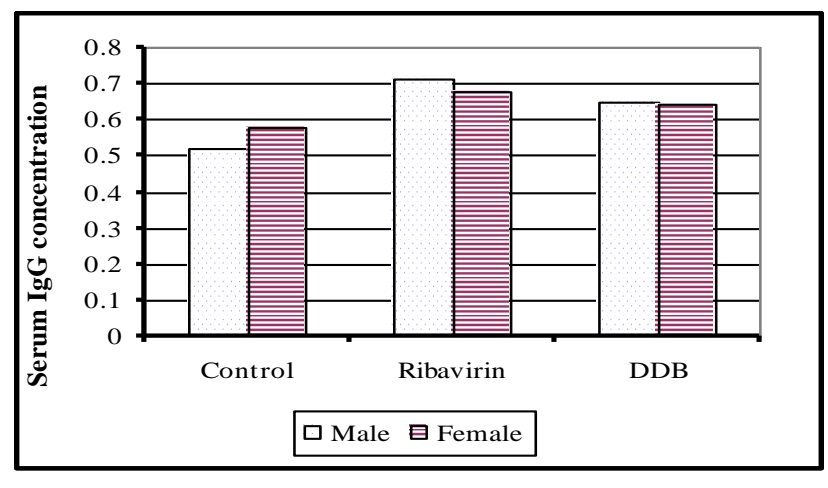

Table and Fig. (1): Effect of intraperitoenal administration of ribavirin or DDB at the level of $1 \mathrm{mg} / \mathrm{kg}$ body weight on serum cortisol concentration $(\mu \mathrm{g} / 100 \mathrm{ml})$ in mature male and female albino rats. Each value represents the mean \pm S.D. of 6 animals. 


\begin{tabular}{|c|c|c|c|}
\hline \multicolumn{4}{|c|}{\begin{tabular}{|l|l|} 
Control & RibavirinDDB \\
\end{tabular}} \\
\hline Male (mean \pm S.E. & 4.80 & \pm 5.40 & 5.00 \\
\hline & 0.24 & $0.41 *$ & $0.24^{\mathrm{n} . \mathrm{s}}$ \\
\hline$\%$ of change & - & $+12.5 \%$ & $4.16 \%$ \\
\hline Female (mean & \pm 4.52 & \pm 5.59 & 4.62 \\
\hline S.E.) & 0.36 & $0.38 *$ & $0.27^{\text {n.s }}$ \\
\hline$\%$ of change & - & $\begin{array}{ll}+ & 23.6 \\
\% & \end{array}$ & $+2.21 \%$ \\
\hline
\end{tabular}

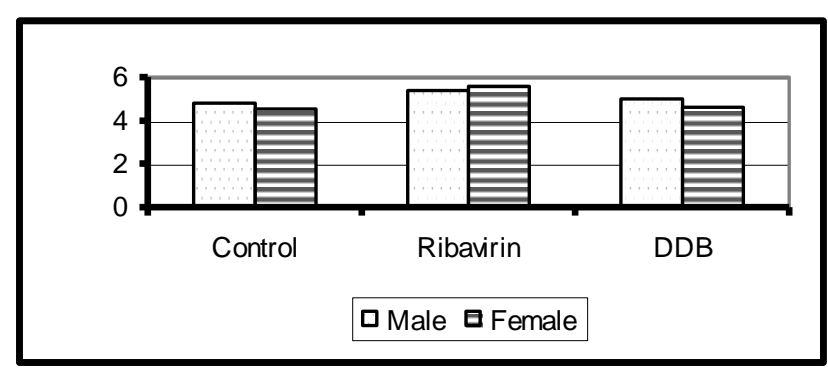

$* \mathrm{P}<0.001 \quad$ n.s. : Non - significance

Table (2) and Fig. (2): Effect of intraperitoneal administration of ribavirin or DDB at the level of $1 \mathrm{mg} / \mathrm{kg}$ body weight on serum $1 \mathrm{gG}$ concentration (IU/100 ml) in mature male and female albino rats. Each value represents the mean \pm S.D. of 6 animals.

\begin{tabular}{|l|c|c|c|}
\hline & Control & Ribavirin & DDB \\
\hline Male (mean \pm S.E. & $\begin{array}{c}135.0 \pm \\
11.5\end{array}$ & $\begin{array}{c}168.3 \pm \\
9.8^{*}\end{array}$ & $\begin{array}{c}159.0 \pm \\
10.4^{*}\end{array}$ \\
\hline \% of change & - & $+24.7 \%$ & $+17.8 \%$ \\
\hline Female (mean \pm S.E.) & $111.6 \pm$ & $141.8 \pm$ & $135.3 \pm$ \\
& 7.2 & $12.1^{*}$ & $21.0^{*}$ \\
\hline$\%$ of change & - & $+27.1 \%$ & $+21.2 \%$ \\
\hline
\end{tabular}

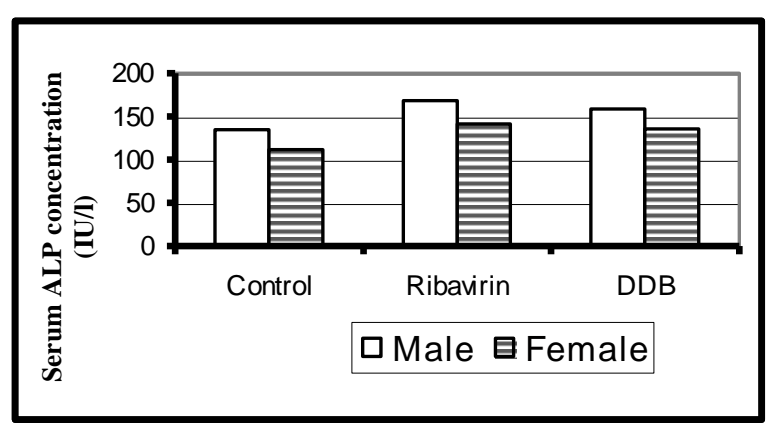

$*(\mathrm{P}<0.001)$

Table and Fig. (3): Effect of intraperitoneal administration of ribavirin or DDB at the level of $1 \mathrm{mg} / \mathrm{kg}$ body weight on serum ALP (IU/L) in mature male and female albino rats. Each value represents the means \pm S.D. of 6 animals.

\begin{tabular}{|l|c|c|c|}
\hline & Control & Ribavirin & DDB \\
\hline Male (mean \pm S.E. & $32.02 \pm$ & $15.17 \pm$ & $20.05 \pm$ \\
& 2.01 & $1.30 *$ & $1.2 *$ \\
\hline$\%$ of change & - & $-52.62 \%$ & $-37.38 \%$ \\
\hline Female (mean \pm S.E. $)$ & $19.98 \pm$ & $13.07 \pm$ & $15.66 \pm$ \\
& 1.85 & $1.10^{*}$ & 0.98 \\
\hline$\%$ of change & - & $-34.58 \%$ & $-21.62 \%$ \\
$*(\mathrm{P}<0.001)$ & &
\end{tabular}

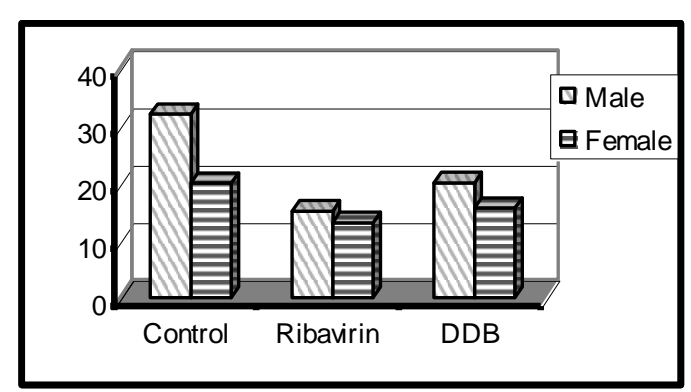

Table and Fig. (4): Effect of intraperitonel administration of ribavirin or DDB at the level of $1 \mathrm{mg} / \mathrm{kg}$ body weight on serum ALT (IU/L) in mature male and female albino rats. Each value represents the mean \pm S.D. of 6 animals. 


\begin{tabular}{|l|c|c|c|}
\hline & Control & Ribavirin & DDB \\
\hline Male (mean \pm S.E.) & $156.0 \pm$ & $150.9 \pm$ & $153.2 \pm$ \\
& 10.51 & $12.2^{\text {n.s. }}$ & $8.7^{\text {n.s. }}$ \\
\hline$\%$ of change & - & $-3.27 \%$ & $-1.8 \%$ \\
\hline Female (mean \pm & $141.8 \pm$ & $136.2 \pm$ & $135.7 \pm$ \\
S.E.) & 12.01 & $12.5^{\text {n.s. }}$ & $11.3^{\text {n.s. }}$ \\
\hline$\%$ of change & & $-3.95 \%$ & $-4.3 \%$ \\
\hline
\end{tabular}

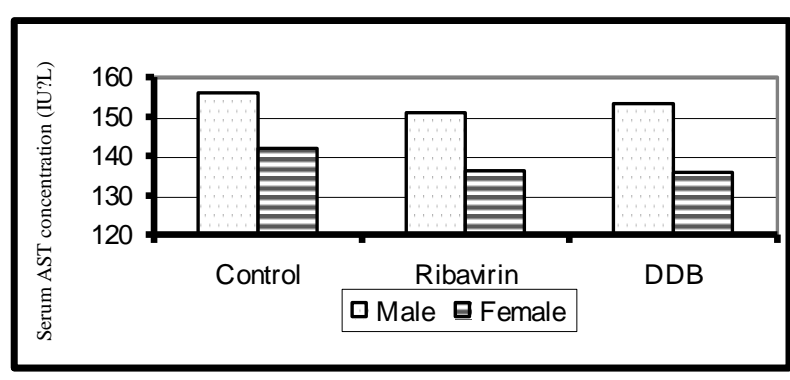

n.s. Non - significance

Table and Fig. (5): Effect of intraperitonceal administration of ribavirin or DDB at the level of $1 \mathrm{mg} / \mathrm{kg}$ body weight on serum AST (IU/L) in mature male and female albino rats. Each value represents the mean \pm S.D of 6 animals.

\begin{tabular}{|l|c|c|c|}
\hline & Control & Ribavirin & DDB \\
\hline Male (mean \pm S.E. & $15.92 \pm$ & $13.37 \pm$ & $16.20 \pm$ \\
& 0.8 & $0.55 *$ & $1.0^{\text {n.s }}$ \\
\hline$\%$ of changed & - & $-16.02 \%$ & $+1.76 \%$ \\
\hline Female (mean \pm S.E.) & $12.82 \pm$ & $9.99 \pm$ & $12.50 \pm$ \\
& 1.0 & $0.81^{*}$ & $0.7^{\mathrm{n} . \mathrm{s}}$ \\
\hline$\%$ of change & - & $-22.07 \%$ & $-2.50 \%$ \\
\hline
\end{tabular}

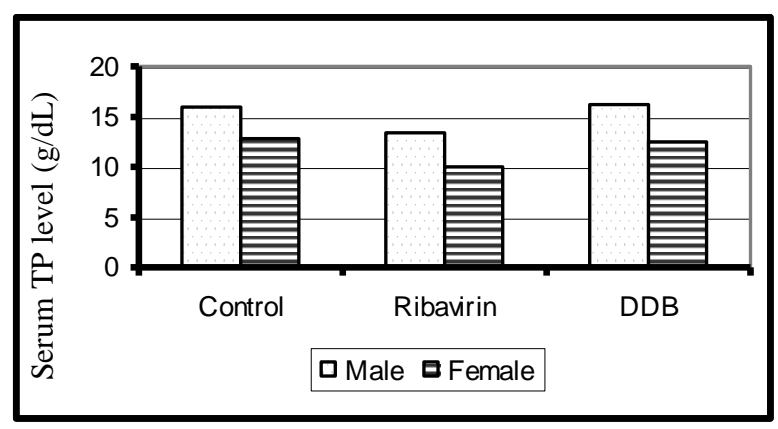

$* \mathrm{P}<0.001 \quad$ n.s.: Non - significance

Table and Fig. (6): Effect of intraperitioneal administration of ribavirin or DDB at the level of $1 \mathrm{mg} / \mathrm{kg}$ body weight on serum TP level $(\mathrm{g} / \mathrm{dl})$ in mature male and female albino rats. Each value represents the mean \pm S.D. of 6 animals.

\begin{tabular}{|l|l|l|l|}
\hline & Control & Ribavirin & DDB \\
\hline Male (mean \pm S.E) & $2.1 \pm$ & $1.49 \pm$ & $2.05 \pm$ \\
& 0.12 & $0.09^{*}$ & $0.75^{*}$ \\
\hline$\%$ of change & - & $-29.05 \%$ & $-2.38 \%$ \\
\hline Female (mean \pm S.E.) & $1.89 \pm$ & $1.52 \pm$ & $1.82 \pm$ \\
& 0.10 & $0.05^{*}$ & $0.04^{\text {n.s }}$ \\
\hline$\%$ of change & $-19.58 \%$ & $-3.70 \%$ & \\
$* \mathrm{P}<0.001$ & n.s Non- significance \\
\hline
\end{tabular}

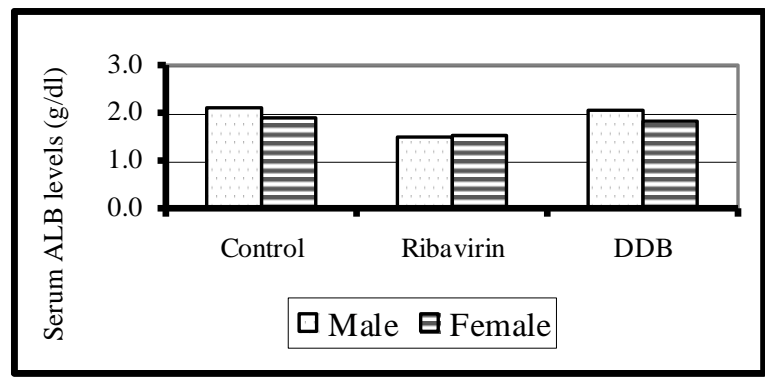

Table (7): Effect of intraperitoneal administration of ribavirin or DDB at the level of $1 \mathrm{mg}$ /kg body weight on serum ALB level (g/dl)) in mature male and female albino rats. Each value represents the mean \pm S.D. of 6 animals. 


\begin{tabular}{|c|c|c|c|}
\hline & Control & Ribavirin & $\overline{\mathrm{DDB}}$ \\
\hline 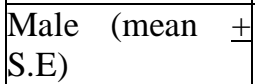 & $\begin{array}{c}225.5 \pm \\
15.3\end{array}$ & $\begin{array}{l}291.8+ \\
19.2 *\end{array}$ & $\begin{array}{l}233.3+ \\
12.8^{\text {n.s }}\end{array}$ \\
\hline$\%$ of change & - & $+29.40 \%$ & $+3.46 \%$ \\
\hline $\begin{array}{l}\text { Female } \quad \text { (mean } \\
\pm \text { S.E. })\end{array}$ & $\begin{array}{c}210.4 \pm \\
16.7\end{array}$ & $\begin{array}{l}280.7 \pm \\
2.01 *\end{array}$ & $\begin{array}{l}215.2 \pm \\
15.3^{\mathrm{n} . \mathrm{s}}\end{array}$ \\
\hline$\%$ of change & - & $+33.41 \%$ & $+2.28 \%$ \\
\hline
\end{tabular}

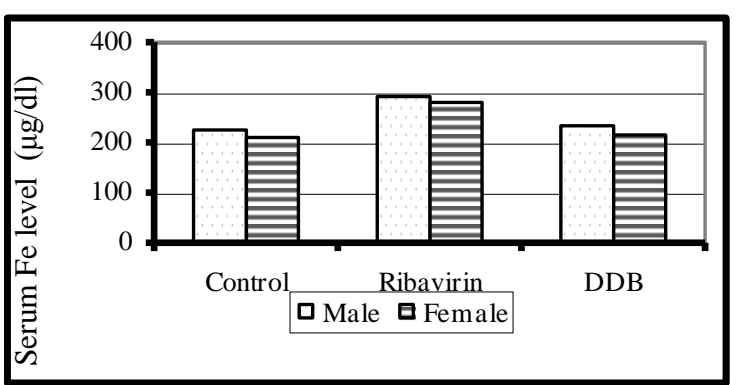

Table and Fig. (8): Effect of intrapertioneal administration of ribavirin or DDB at the level of $1 \mathrm{mg} / \mathrm{kg}$ body weight on serum Fe level $(\mu \mathrm{g} / \mathrm{dl})$ in mature male and female albino rats. Each value represents the mean \pm S.D. of animals.

\section{Discussion}

The present study includes the comparison between antiviral ribavirin and hepatoprotective DDB drugs, with respect to their biochemical effects associated with their clinical utility.

The result of cortisol hormone and ALP detection showed that, administration of the two drugs in both male and female rats produce significant increase $(\mathrm{P}<0.001)$ in serum cortisol and ALP concentration, this, may be due to the inflammatory tissue response of the injected host . The inflammation stimulate the pituitary corticotropin hormone which stimulates the adrenal cortex to release the corticosteroids cortisone and cortisole as anti-inflammatory agents This abservation agree with the work of (Li et al., 1992, Hibi et al., 1997, Ohno et al., 1998, Montor et al., 1998, Johnson et al., 2002 and Marieke and Michael 2004).

They establised the antiviral hepatoprotective drugs as ribavirin, interferone- $\alpha$ and DDB stimulate the steroid hormones secretion and increase plasma cortisol levels.

In respect to antigliadin $(\operatorname{IgG})$ the results showed significant increase $(\mathrm{P}<0.001)$ in its serum level of both male and female ribavirin treated animals, while it did not change in DDB treated animal. Thus ribavirin considered as antiviral drug and its mode of action could be summarized as the ribavirin resmbles guanosine in its structure, which may exert its antiviral effect by reducing intracellular guanosine nucleotide pools, thereby inhibiting DNA and DNA synthesis. Also, in cells, ribavirin is phosphorylated by cellular kinas and converted to ribavirin monophosphate (RMP) which inhibits inosine monophosphate dehydrogenase, an enzyme essential for the synthesis of guanosine triphosphate (GTP), which is essential component for DNA synthesis (Prescott et al.,
2000 , Johnson et al., 2002 and Saad and Fawzy, 2004), this is not concordant with DDB drug, but its hepatoprotective effect may be attributed to its regulation on enzymes involved in toxic agent metabolism, and its protective effect against mitochandria injury caused by toxins. ( $\mathrm{Li} \mathrm{Y}$ and Li Y , 2001; Lu H and Li Y 2002 and Huber et al., 2004).

Furthermore, both drugs reduced serum ALT (significant decrease $\mathrm{P}<0.001$ ), but not exhibited marked reduction in serum AST ( non significance decrease).The same results reported by Chai - Jan Chang et al., (2000), he reported, that ALT are more closely associated with hepatic infection than AST, and hepatic infection play an important role in the etiology of raised ALT activity among drug abusers. Also, Johnson et al., (2002) stated, that mechanism of ribavirin action as it is a guanin analogue that is phosphorylated into its most active form, ribavirin- triphosphate. This compound competes with adenosine - triphosphate and guanine - triphosphate for binding sites at the polymerase, as well as inhibiting transferase enzymes, thus in patients receiving ribavirin monotheraby, serum ALT were reduced in a considerable proportion. These observations also agree with the work of Bizollon et al., (1999); Shane et al., (2000), Lise et al., (2001) and Pascal Veillon et al., (2003).

Moreover, Huber et al., (2004) said that in vitro experiments with hepatocytes resulted in a significant decrease of hepatocellular ALT in the DDB treated cells, suggesting that DDB affects the synthesis and / or degradation of ALT in liver cells. Unlike ALT, AST levels were not affected.

Similar results demonstrated by $L i Y$ and Li Y (2001) and Lu H and Li Y (2002), they concluded, that the protective action of DDB 
attributed to its regulation on enzymes and by increasing the detoxyfying metabolism in the liver.

Administration of ribavirin induced a significant decrease $(\mathrm{P}<0.001)$ of serum ALB and TP levels, while DDB treated animals showed non - significant decrease in ALB and TP level in serum . Ribavirin injection in rats or mice induces a behavioural pattern referred to as sickness behaviour which includes increased sleep, reduced locomotor activity decreased sucrose consumption, loss of appetite, weight loss and decreased social explor-ation, these symptoms resemble the vegetative symptoms of depression in human (De Sarro et al., 1990, Goodman and Gilman's 1996, Robert et al., 2000 and Marieke et al. 2004). All these symptoms and long term ribavirin injection cause inflammation of liver cells which are responsible for albumin synthesis.

Also, remarkable increase $(\mathrm{P}<0.001)$ in serum $\mathrm{Fe}$ concentration under the effect of ribavirin considered one of the side effects of ribavirin administration. Patrick et al., (2002) reported, that the most common adverse effect of ribavirin administration is reversible anemia caused by a combination of transient suppression of erythropoiesis and extravascular hemolysis from accumulation of phosphorylated drug in red blood cells, this hemolysis increase Fe level in serum, the same results were obtained by Thevenot et al., (1997) ,Robort et al., (2000), Shane et al., (2000), Lise et al., (2001) and Johnson et al., (2002).

Finally, although, ribavirin has many side effects, it appears to be a pleiotropic agent with many intrinsic mechanisms that can influence its overall antiviral properties. Many investigators are favoring the immun-omodulatory mechanism; although the possibility that ribavirin is a viral RNA mutagen is also gaining attention. Johnson et al. (2002) said, what we have learned so far is perhaps the tip of the iceberg for ribavirin. Wherease, DDB considered as one of hepatoprotective drugs and has not remarkable side effects as ribavirin, but little is known about DDB interaction within cellular content and further studies will be attended .

\section{References}

1. Alo Nag, Abhishek Datta, Kyung Yoo, Dibyendu Bhattacharyya, Amit Chakrabortty, Xinhi Wang, Betty L. Slagle and Paradip Raychaudhuri (2001): $\mathrm{DDB}_{2}$ induces nuclear accumula- tion of the hepatitis $\mathrm{B}$ virus $\mathrm{X}$ protein independently of binding to $\mathrm{DDB}_{1}$. J. of Virology Vol. 75, No. 21: 10383-10392.

2. Bizollon T., Palazzo U., Ducerf C., Chevallier M., Elliott M. and Baulieux J. (1999): Pilot study of the combination of interferon - alpha and ribavirin as therapy. Hepatology 2 (2): 500-504.

3. Chai- Jan Chang, Ying- Chin KO and Hong - Wen Liu (2000). Serum alanine aminotransferase level in relation to hepatitis $\mathrm{B}$ and $\mathrm{C}$ virus infections among drug abusers in an area hyperendemic for hepatitis B. J. digestive desease and Science 45 (10): 1949-1952.

4. Chang J., Guo X., Cheng S., Guo R., Chen, R. and Zhao K. (2004): Efficient synthesis of gamma-DDB. Bioorg Med. Chem. Lett, 3, 14 (9): 2131-2136.

5. Chiu P. Y., Tang M. H., Mak D. H., Poon M. K. and KO K. M. (2003): Hepatoprotective mechanism of schisandrin B: role of mitochondrial glutathione antioxidant status and heat shock proteins. Free Radic Biol. Med. 15, 35 (4): 368-380.

6. Davis G. L., Esteban-Mur R., Rustgi V., Hoefs J., Gordon S., Trepo C., Schiffman, M. and Albrecht, J. (1998): Interferon alpha $-2 b$ alone or in combination with ribavirin for the treatment of relapse of chronic hepatitis $\mathrm{C}$ virus. N. Engl. J. Med. 339: 1493-1499.

7. Dean J. R., Ando D. J. and Metcalf E. (1997): Atomic absorption and plasma spectroscopy. New York, John Wiley and Sons.

8. De Sarro A., Naccari F., De Sarro G. B., Amendola D., Rotiroti D. and Trimarch G. R. (1990): Repairing-induced behavioral body temperature and electrocortical spectra effects in the rat. Arch. Int. Pharmacodyn. Ther. 304: 125-135.

9. Doumas, B. J.; Watson, W. A. and Biggs, H.G. (1971): Albumin standards and the measurement of serum albumin with bromocresol green Clin. Chem. Acta, 31: 87-95.

10. Dusheiko G., Main J., Thomas H., Richard O., Lee C., Dhillon A., Rassam S., Fryden A., Reesink H., Bassendine M., Norkrans G., Cuypers T., Lelie N. and Weiland O. (1996): Ribavirin treatment for patients with chronic hepatitis C: results of a placebo- controlled study. J. Hepatol. 25: 591-598...

11. Dutta, Bergman, (2003): A descriptive narrative of healthy eating Health Mark Q. 20 (30): 81-101. 
12. Francoise Bergametti, Delphine Sitterlin and Catherine Transy (2002): Turnover of hepatitis B virus $\mathrm{X}$ protein is regulated by damaged DNA - binding complex. UREG (INSERMU 163), Institute Pasteur, Paris, France.

13. Goodman and Gilman's (1996): Respiratory tract infection (P.454-456) Me Graw - Hill New York. U.S.A.

14. Hall C. B., Mc Bride J. T., Walsh E. E., Bell D. M., Gala C. L., Hildreth S. and Hall W. J. (1983): Aerosolized ribavirin treatment of infants with respiratory syncytial viral infection N. Engl. J. Med. 308:1443-1447.

15. Hibi H., Yokoi, K. and Yamamoto, M. (1997): Effect of alpha interferon on sperum production, concentration and motility in the rat. Int. J. Urol. 4 (6): 603-607.

16. Huber R., Hockenjos B. and Blum HE. (2004): DDB treatment of patients with chronic hepatitis. Hepatology 39 (6): 17321733.

17. Hultgren C., Milich R., Werland O. and Sallberg M. (1998): The antiviral compound ribavirin modulates the $\mathrm{T}$ helper (Th) $1 /$ Th2 subset balance in hepatitis B and $\mathrm{C}$ virus - specific immune responses. $\mathrm{J}$. Gen virol. 79: 2381-2391.

18. Hwang B. J., Liao J. C. and Chu G. (1996): Isolation of a cDNA encoding a UV- damaged DNA binding factor defective in xeroderma pigmentosum group E cells. Mutat. Res. 362: 105-117.

19. Hwang, B. J., Ford J. M., Hanawalt P. C. and Chu G. (1999): Expression of the P 48 xeroderma pigmentsum gene is P53 dependent and is involved in global genomic repair. Proc. Natl - Acad. Sci. USA 96: 424-428.

20. Johnson Y. N., Lau Robert C., Tam T., Jake Liang and Zhi Hong (2002): Mechanism of action of ribavirin in the combination treatment of chronic $\mathrm{HCV}$ infection. Hepatology, Vol. 35, No. 5 10021009.

21. Lise, L. Kjaergard, Kim Krogsgaard and Christian Gluvd (2001): Interferon alpha with or without ribavirin for chronic hepatitis C.; Systematic review of randomised trials. BMJ Vol. 323 (17) : 1151-1155.

22. Li Y and Li Y (2001): Effect of dimethyl diphenyl bicarboxylate (DDB) on 9-amino 1, 2, 3, 4 - tetrahydroacridine - induced hepatotoxicity in mice. Yao, Xue Xue Bao 36 (7): 493-497.
23. Li Y., Paranawithana S. R., Yoo J. S., Ning S. M., Ma B. L., Lee M. J., Liu G. T. and Yang C. S. (1992): Induction of liver microsomal cytochrome P-450 2B1 by dimethyl diphenyl bicarboxylate in rats. Zhongguo Yao Li Xue Bao, 13 (6): 485490.

24. Lowry O. H., Rosebrough N. J., Farr A. L. and Randall R. J. (1951): Protein measurement with the foline phenol reagent. J. Biol. Chem. 193: 265-275.

25. Lu H. and Li Y. (2002): Effect of dimethy diphenyl bicarboxylate on the metabolism and hepatotoxicity of aflatoxin B1 in rats. Yao Xue Xue Bao, 37 (10): 753-757.

26. Marieke C., Wichers, and Michael Maes (2004): The role of indoleamine 2,3 dioxygenase (IDO) in the pathophysiology of interferon $-\alpha$ - induced depression . J. Psychiatry Neurosci, 29 (1): 1-7.

27. Martin M. J., Navas S. , Quiroga J. A., Pardo M. and Carreno V. (1998): Effects of the ribavirin- interferon alpha combination on cultural peripheral blood mononuclear cells from chronic hepatitis C. patients. Cytokine 79: 2381-2391.

28. McHutchinson J. G., Gordon S. C., Schiff E. R., Mitchell M. D., Shiffmann M. L., Lee W. M., Rustgi V. K., Goodman Z. D., Ling M. H., Cort S. and Albrecht J. K. (1998): Interferon alpha 2B alone or in combination with ribavirin as initial treatment for chronic hepatitis. C. N. Engl. J. Med. 339: 1485-1492.

29. Montor J. M., Mendoza M. E. and Romano, Mc. (1998): Effect of human and murine interferon - alpha on steroid production by rat ovarian cells. Life. Sci. 62 (19): 1733-1744.

30. Nakamura K., Yoshida M., Uchiwa H., Kawa Y. and Mizoguchi M. (2003): Down - regulation of melanin synthesis by a biphenyl derivative and its mechanism. Pigment cell Res. 16 (5): 494-500.

31. Ning Q. , Brown D., Parodo J., Cattral M., Fung L., Gorczynski R., Cole E., Fung L., Ding J. W., Liu M. F., Rotstein O., Phillips M. J. and Levy G. (1998): Repairing inhibits viral - induced macrophage production of tumor necrosis factor. J. Immunol. 160: 3487-3493.

32. Ohno Y., Fujimoto M., Nishimura A. and Aoki N. (1998): Change of peripheral levels of pituitary hormones and cytokines after injection of interferon - beta in patients with chronic hepatitis C. J. Clin. Endocrinol Metab. 83 (10): 3681-3687. 
33. Pascal Veillon, Christopher Payan, Gaston Picchio, Michele Maniez and Francoise Lunel (2003): Comparative evaluation of the totoal hepatitis $\mathrm{C}$ virus core antigen, Branched, DNA and Amplicor monitor assays in determining viremia for patients with chronic hepatitis $\mathrm{C}$ during interferon plus ribavirin combination therapy . J. Antimicrob. Chemother, 51: 93-99.

34. Patrick J. Gavin MD and Benz Katz MD (2002): Intravenous ribavirin treatment for sever adenovirus disease in immunocompromised children. PEDIATRICS vol. 110 No. 1: 1-8.

35. Prescott J. F, Baggot J. D. and Walker R. D. (2000): Antimicrobial therapy in Veterinary medicine. $3^{\text {rd }}$. Ed. Iowa State University press Ames.

36. Ralph M. Aloisi (1988): Principles of immunology and immunodiagnostics. Lea and Febiger, under the international Copyright Union. Columbia, Maryland.

37. Reichard O., Norkrans G., Fryden A., Braconier I. H., Sonnerborg A. and Weiland O. (1998): Randomized double blind, placebo controlled trial of interferon alpha $2 \mathrm{~B}$ with and without ribavirin for chronic hepatitis C. Lancet 351: 83-87.

38. Reitmang S. and Frankel S. (1957): A colorimetric method for the determination of serum glutamic oxaloacetic acid and glutamic pyruvic transaminase. Am. J. Clin. Pathol. 28: 53-56.

39. Robert C., Tam Kanda Ramasamy, Josie Bard, Charmaine Lim and Devron R. Averett (2000): The ribavirin analoge ICN 17261 demonstrates reduced toxicity and antiviral effects with retention of both immunomdulatory activity and reduction of hepatitis - induced serum alanine aminotransferase levels. Antimicrobial Agents and Chemotherapy Vol. 44, No. 5: 1276-1283.

40. Roy, A. V. (1970): Arapid method for alkaline phosphatase estimation. Clin. Chem. 16: 431-442.

41. Saad M. A. A. and Fawzy H. G. I. (2004): Antiviral action of ribavirin on Foot and Mouth disease virus replication in cell cultures and laboratory animals. $7^{\text {th }}$ Vet. Med. Zagazig. Conference.

42. Schek N., Bartenschlager R., Kuhn C. and Schaller H. (1991): Phosphorylation and rapid turnover of hepatitis $\mathrm{B}$ virus $\mathrm{X}-$ protein expressed in Hep G2 cells from a recombinant vaccinia virus. Oncogene 6: 1735-1744.
43. Schlaghecke R., Komely E., Santen R. T. and Ridderskamp P. (1992): The effect of long-term glucocorticoid on pituitary adrenal responses to exogenous corticotropin - releasing hormone. New Engl. J. Med. 326: 226-230.

44. Selvin S. (1996): Statistical analysis of epidemiologic data. Oxford Univ. Press, New York, P. 44-78.

45. Shane Crotty, David Maag, Jamie J. and Zhi Hong (2000): The broad- spectrum antiviral ribonucleoside ribavirin is an RNA virus mutagen. Nature Medicine. Vol. 6 No. 12.

46. Sidwell RW, Huffman JH, Khare GP, Allen LB, Kwiatkowski JT and Robins R. K. (1972): Broad- spectrum antiviral activity of virazole : 1- beta - Dribofuranosyl 1,2,4- trizole-3- carboxamide. Science 177: 705-706.

47. Smith R. A. and Kirkpatrick W. (1980): Ribavirin, a broad spectrum antiviral agent . Academic, New York Vol. XIII, 237.

48. Smith R. A., Knight V. and Smith J. A. D. (1984): Clinical applications of ribavirin. Academic, New York Vol. XIX, 222.

49. Streeter D. G. (1973): Mechanism of action of 1- beta - D- ribofuranosyl -1,2,4triazole-3 carboxamide (virazole), a new broad- spectrum antiviral agent. Proc. Nat. Acad. Sci. USA. 70:1174-1178.

50. Thevenot T., Mathurin P. , Moussalli J., Perrin M., Plassart F. and Blot C. (1997): Effect of cirrhosis, interferon and azathioprine on adverse events in patients with chronic hepatitis $C$. treated with ribavirin. J. of Viral Hepatits .4 (4): 243253.

51. Tam R. C., Lim C., Bard J. and Pai B. (1999): Contact hypersensitivity responses following ribavirin treatment in vivo are influnced by type 1 cytokine polarization. J. Immunol. 163: 3709-3717.

52. Tang J. Y., Hwang B. J., Ford J. M., Hanawalt P. C. and Chu G. (2000): Xeroderma pigment sum P48 gene enhances global genomic repair and suppresses UV- induced mutagenesis. Mol. Cell. 5: 737-744.

53. Wittschieben B. Bo and Wood, RD (2003): DDB complexities. DNA Repair (Amst.) 18, 2 (9): 1065-1069.

54. Wyde P. R. (1998): Respiratory syncytial virus (RSV) disease and prospects for its control. Antiviral Res. 39: 63-79. 
التأثيرات البيوكميائية لعقاري الريبافيرين (مضاد فيروسي) وال دي دي بي

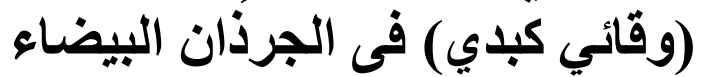

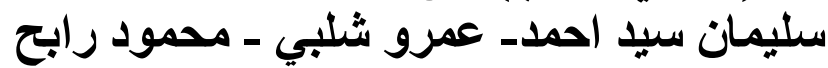

قسم علم الحيوانـ كلية العلوم- جامعة الزقازيق- جمهورية مصلية مصر العربية

بر غم تعدد عقار ات عـلاج الالتهابـات الكبديـة الفيروسية إلا أن هنـالك أبحـاث

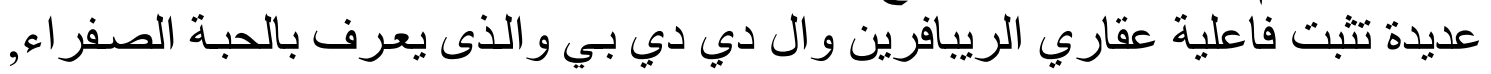

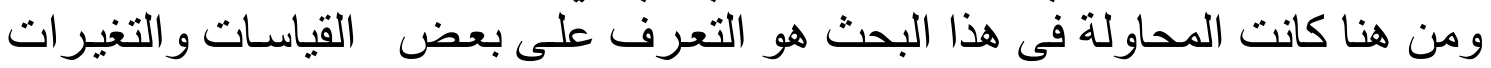

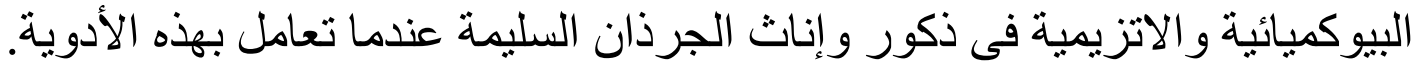

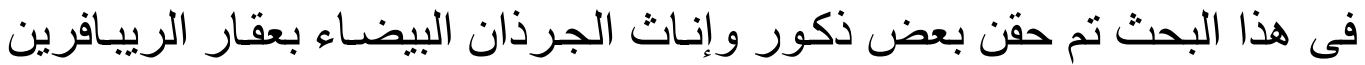

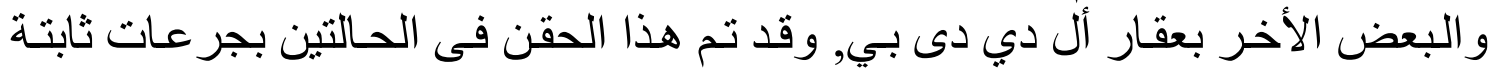

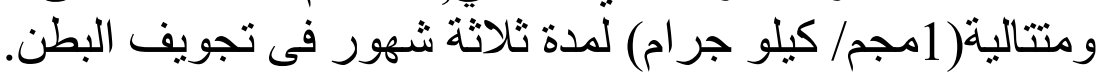

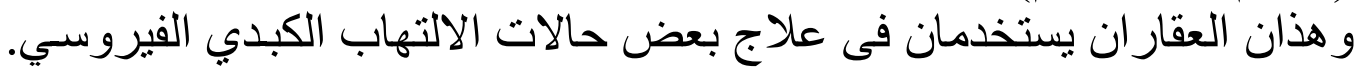

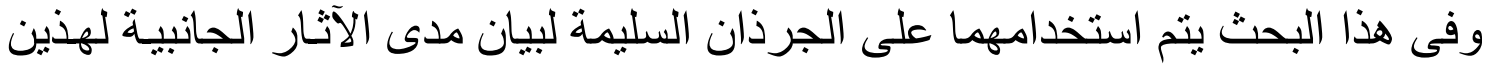

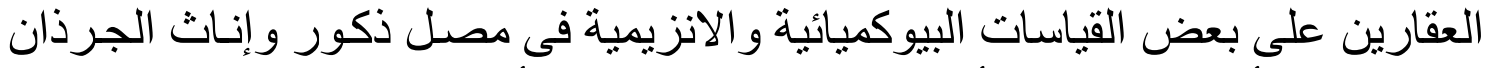

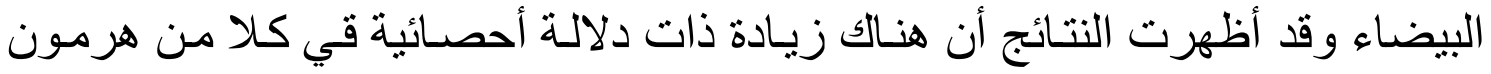

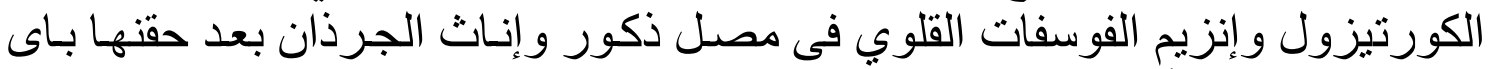

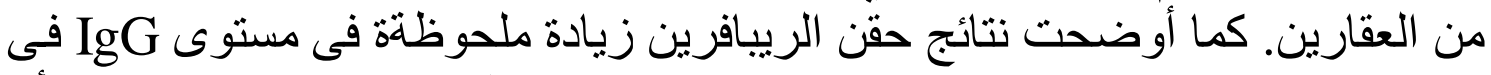

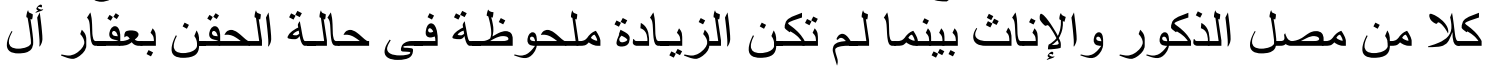

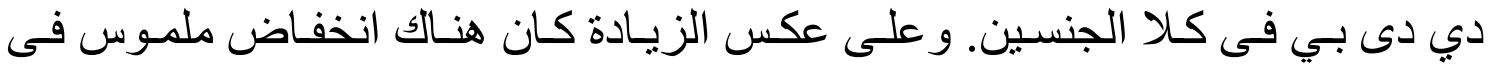

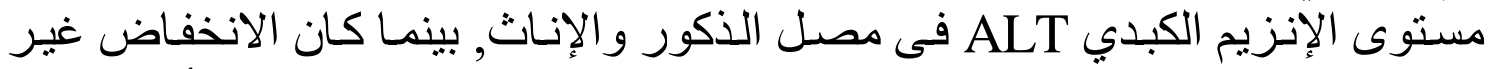

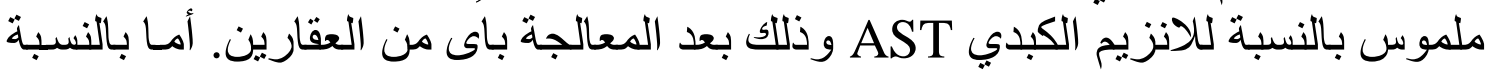

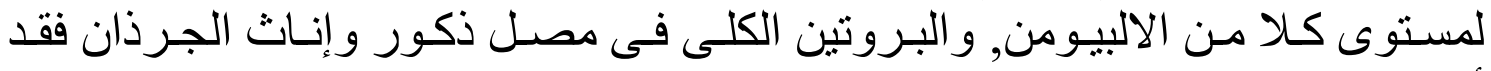

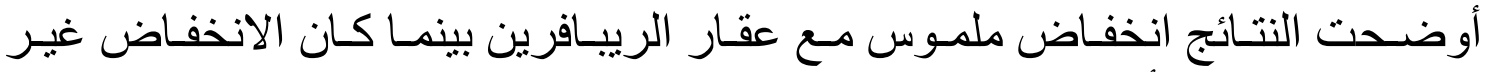

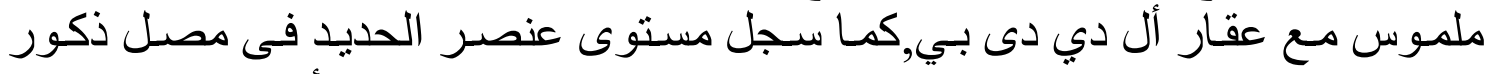

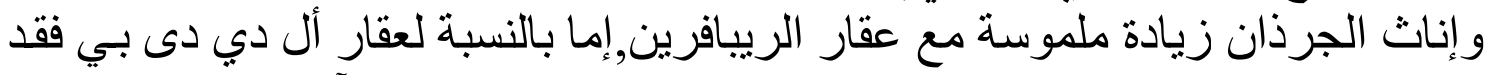

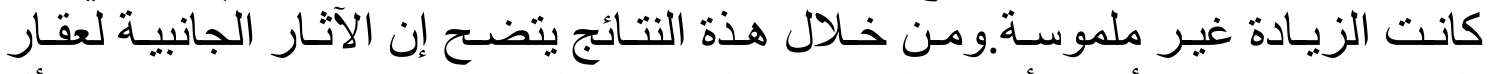

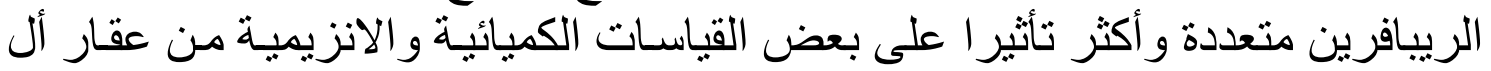
دي دى بي مع إثبات التأثير المناعي الايجير التئي لكلا العقارين. 